\title{
DIET AND ECTOPARASITES OF THE SOUTHERN SHORT-TAILED SHREW (BLARINA CAROLINENSIS) IN LOUISIANA
}

\author{
Terry L. Sylvester ${ }^{1}$, Justin D. Hoffman ${ }^{2}$, and Eddie K. Lyons ${ }^{1}$
}

\begin{abstract}
Diet items and ectoparasites were identified from 15 southern short-tailed shrews (Blarina carolinensis) captured during a one-year study (December 2009-November 2010). Twenty different diet items were found in 13 southern short-tailed shrews. Collectively, insects made up the bulk of these shrews' diet (92\%), with Diptera and Hymenoptera being most prevalent. Plant material and arachnids occurred $46 \%$ of the time. Six of the diet items identified are new reports for the southern short-tailed shrew. Nine ectoparasite species were collected from 11 of the southern short-tailed shrews, comprising 8 species of mites and one species of tick. Orycteroxenus soricis and Androlaelaps fahrenholzi were the most frequent (36\%) ectoparasites collected. Two of the ectoparasites (Ornithonyssus bacoti and Ixodes scapularis) are new host records, and 5 of the 8 species of mites collected were not previously reported as occurring in Louisiana.

RESUMEN.-Se identificaron elementos de la dieta y ectoparásitos en 15 musarañas de cola corta del sur (Blarina carolinensis) que se capturaron durante un estudio realizado durante un año (diciembre de 2009-noviembre de 2010). Se encontraron veinte elementos diferentes de la dieta en 13 musarañas de cola corta del sur. De manera conjunta, los insectos constituyeron la mayor parte de la dieta de las musarañas (92\%) siendo Diptera e Hymenoptera los más prevalentes. El $46 \%$ de las veces se encontró material vegetal y arácnidos. Seis de los elementos de la dieta identificados son reportes nuevos para la musaraña de cola corta del sur. Se colectaron nueve especies de ectoparásitos de 11 de las musarañas de cola corta del sur que comprendieron ocho especies de ácaros y una especie de garrapata. Orycteroxenus soricis y Androlaelaps fahrenholzi fueron los ectoparásitos colectados más frecuentes (36\%). Dos de los ectoparásitos (Ornithonyssus bacoti e Ixodes scapularis) son nuevos registros en estos huéspedes y cinco de las ocho especies de ácaros colectados no se habían reportado anteriormente para Louisiana.
\end{abstract}

Short-tailed shrews previously were considered one species, Blarina brevicauda. Systematic studies of the genus Blarina have resulted in the recognition of 3 species (Handley 1971, Genoways and Choate 1972, George et al. 1982). The designation of separate species of Blarina resulted in a gap in knowledge of those species' natural history. One of the newly recognized species is the southern short-tailed shrew (Blarina carolinensis), which occurs throughout the southeastern United States (Genoways and Choate 1998). The southern short-tailed shrew is distributed throughout Louisiana, except in the coastal parishes (Lowery 1974). It occurs in wooded areas (pine and mixed hardwood), in brushy thickets next to forests (Hatchell 1964, Lowery 1974, Martin et al. 1991), and in grassland and meadows where adequate cover and food exist (Baumgardner et al. 1992, Schmidly 1994).

Few studies have been conducted on the diet and ectoparasites of southern short-tailed shrews (Genoways and Choate 1998), and no extensive studies have been completed in Louisiana (Lowery 1974). Currently one report exists on the diet of the southern shorttailed shrew from the western portion of its geographic range in East Texas (Ladine and Muñoz 2010). However, most of what is presently known about the diet and parasitic burden of this species is derived from studies completed in the eastern portion of its geographical range (Calhoun 1941, Hays and Guyton 1958, Whitaker 1982, Pascal 1984, Whitaker et al. 1994, Whitaker and Ruckdeschel 2006, Nims et al. 2008). The objective of this study is to identify diet items and ectoparasites of the southern short-tailed shrew in southwestern Louisiana.

This study was conducted over one year (December 2009-November 2010) at 2 locations in Calcasieu Parish, Louisiana. The main study area was at Sam Houston Jones State Park $\left(30.30^{\circ} \mathrm{N}, 93.26^{\circ} \mathrm{W}\right)$, which consisted of

${ }^{1}$ McNeese State University, Harold and Pearl Dripps Department of Agricultural Sciences, Lake Charles, LA 70609

${ }^{2}$ Corresponding author. McNeese State University, Department of Biological and Health Sciences, Lake Charles, LA 70609. E-mail: jhoffman@mcneese.edu 
multiple habitat types including open pine islands, native grasslands, dense pine woods, and bottomland hardwoods. The second study area was in Lebleu Settlement, a farm community in the northeastern portion of the parish $\left(30.27^{\circ} \mathrm{N}, 93.08^{\circ} \mathrm{W}\right)$. The habitat there was tracts of mixed native grasses bordered by cow pastures and Bayou Serpent, with areas of deciduous woods between the grass and bayou.

Shrews were captured using arrays of pitfall traps. Each array consisted of a central trap with $3.80 \mathrm{~m} \times 10.16 \mathrm{~cm}$ drift fences radiating out in 4 separate coordinate directions and a terminal trap at the end of each fence, for a total of 5 traps in each array. All traps were buried $18-23 \mathrm{~cm}$ deep. The traps were uncovered for 30-52 days in each of 4 trap seasons: winter (9 December-8 January), spring (9 March-15 April), summer (7 June-29 July), and fall (20 October-28 November). A total of 50 traps were assembled at Sam Houston Jones State Park for the winter and spring trapping seasons. Ten more traps were added for the summer trapping season at Sam Houston Jones State Park, and 15 were added in Lebleu Settlement. For the fall trapping season, the 15 traps were removed from Lebleu Settlement and installed at Sam Houston Jones State Park. Shrews were euthanized in the field with chloroform (Gannon et al. 2007) according to protocols approved by the McNeese State University Institutional Animal Care and Use Committee (Animal Use Protocol IACUC \#09112009).

Diet of the shrews was determined by removing the gastrointestinal tract, which was placed in a glass culture dish with water. Under a dissecting microscope, the intestines were cut open and the food items were collected and placed in collection vials with $70 \%$ isopropyl alcohol for preservation and identification. The fur of the shrews was combed out with a louse comb and then brushed over a culture dish containing 70\% isopropyl alcohol to collect any loose or lightly attached ectoparasites. The collection bags were turned inside out over the culture dish and rinsed off with alcohol to collect any ectoparasites that were in the bag. Under a dissecting microscope, the fur and skin of the shrews were examined with forceps and a probe to remove attached ectoparasites.

The total capture rate (trap success percentage) for our study was determined by dividing the number of shrews captured by the number of trap-nights (number of traps $\times$ the number of nights the traps were open). The capture rates were compared between studies as an indication of the relative abundance of the southern short-tailed shrew over its geographical range. Shrews were prepared as voucher specimens and stored in the W.A.K. Seale Vertebrate Museum at McNeese State University. Accession numbers for the shrews include 9324-9356.

Trapping occurred on 158 days for a total of 7000 trap-nights. Fifteen shrews were collected over the course of the study. Six shrews were captured in the winter (9 December-8 January), 5 in the spring (9 March-15 April), 3 in the summer ( 7 June-29 July), and 1 in the fall (20 October-28 November). Ten shrews were captured from grassland habitats. One shrew each was captured from dense pine woods and a hardwood bottomland, and 3 were captured from open pine islands. Capture rates were $0.45 \%$ in winter, $0.29 \%$ in spring, $0.17 \%$ in summer, and $0.05 \%$ in fall, for an average rate of $0.21 \%$ for the entire study.

Our capture rate of $0.21 \%$ reported here for Calcasieu Parish, Louisiana, combined with published information on capture rates of the southern short-tailed shrew throughout its geographical range, suggests a decrease in relative abundance from east to west. Whitaker and Ruckdeschel (2006) reported a capture rate of $1.6 \%$ on Cumberland Island, Georgia. Hatchell (1964) trapped shrews in central and north central Louisiana with a capture rate of $0.65 \%$, and Schmidly (1983) reported a capture success of $0.19 \%$ from the Big Thicket National Preserve in southeastern Texas.

Most shrews in our study were captured in flat grasslands that were often damp without being saturated and on open pine islands that were adjacent to shallow swamps. Only one shrew was captured from upland pine woods, which remained dry throughout the study. Likewise, only one was captured from a bottomland habitat, which was inundated with water in the winter and spring and remained saturated until late in the summer. Genoways and Choate (1998) characterized the southern shorttailed shrew as a habitat generalist, and although it is found in multiple habitat types, it is most abundant in the wetter habitats available in a region. One study in Louisiana reported that southern short-tailed shrews selected drier upland pines and avoided the poorly drained 
TABLE 1. Percent frequency of diet items recovered from 13 southern short-tailed shrews (Blarina carolinensis) in southwestern Louisiana, 2009-2010.

\begin{tabular}{lc}
\hline Food item & Frequency $(\%)$ \\
\hline Animalia (total) & 100 \\
Arthropoda (total) & 100 \\
Insecta (total) & 92 \\
Insecta (unknown) & 23 \\
Diptera & 23 \\
Hymenoptera (Formicidae) & 23 \\
Isoptera & 15 \\
Coleoptera adult & 15 \\
Orthoptera (total) & 15 \\
Grylacrididae & 8 \\
Gryllidae & 8 \\
Lepidoptera (larvae) & 8 \\
Lepidoptera (adult) & 8 \\
Mantodea & 8 \\
Hemiptera & 8 \\
Neuroptera: Chrysopidae & 8 \\
Arachnida (total) & 46 \\
Araneae & 39 \\
Opiliones: Phalangidae & 8 \\
Chilopoda & 8 \\
Entognatha (total) & 15 \\
Collembolla & 8 \\
Protura & 8 \\
Diplopoda & 8 \\
Malacostraca (Isopoda) & 8 \\
Plantae (total) &
\end{tabular}

TABLE 2. Percent frequency of ectoparasite species collected from 11 southern short-tailed shrews (Blarina carolinensis) in southwestern Louisiana, 2009-2010.

\begin{tabular}{lc}
\hline Species & Frequency (\%) \\
\hline Laelapidae & 36 \\
$\quad$ Androlaelaps fahrenholzi & 18 \\
$\quad$ Echinonyssis blarinae & 9 \\
$\quad$ Haemogamasus harperi & \\
Glycyphagidae & 36 \\
$\quad$ Orycteroxenus soricis & \\
Myobiidae & 18 \\
$\quad$ Blarinobia simplex & \\
Pygmephoridae & 18 \\
$\quad$ Pygmephorus tamiasi & \\
Macronyssidae & 9 \\
Ornithonyssus bacoti & \\
Cheyletidae & Eucheyletia bishoppi \\
Ixodidae & 9 \\
$\quad$ Ixodes scapularis & 18 \\
\hline
\end{tabular}

bottomlands that have saturated soils at any time (Hatchell 1964). Handley (1971) reported similar findings in the Great Dismal Swamp, where shrews were collected on the margins of the swamp but never in the swamp. Whitaker and Ruckdeschel (2006) captured the species from a pine-oak scrub at the edge of a temporary pond and in a wetland adjacent to a wooded swamp. Our capture of most shrews from moderately moist habitats in close proximity to shallow swamps seems to support the findings from these other studies.

The gastrointestinal tracts of 13 out of 15 shrews examined contained diet items. Overall, animal material, specifically insects, made up the bulk of these shrews' diet (frequency of occurrence: 92\%). Among the insects, Diptera and Hymenoptera were most common (23\%). Arachnids and plant material each occurred in $46 \%$ of the shrews examined (Table 1). Nine ectoparasite species ( 8 mites and 1 tick) were collected from 11 out of 15 shrews examined (Table 2). Orycteroxenus soricis and Androlaelaps fahrenholzi were the most prevalent ectoparasites (36\%).

A high variation in the food items taken by southern short-tailed shrews was observed, allowing for a relatively large species representation from a small number of shrews. In all, 6 new diet items for the southern shorttailed shrew were recorded (Chrysopidae, Mantodea, Gryllacrididae, Isopoda, Isoptera, and Protura). The diets of shrews collected in grassland habitats showed the most diversity of diet items (13). The winter and spring seasons proved to be the most productive in terms of capturing shrews (5 each), and the majority of food items were taken from shrews collected during the winter, spring, and summer seasons.

The diets of southern short-tailed shrews in our study are similar to the diets of those taken in other areas of the species' geographic range in that the bulk of food items chosen were insects. However, when more specific diet items are considered, there are some notable differences in our results. We found that Diptera (flies), Formicidae (ants), Araneae (spiders), and plant material were the most eaten items. In northwestern Tennessee, Calhoun (1941) found that Coleoptera (beetles-adults and larvae) made up the bulk of the food identified in the southern short-tailed shrew, with Lepidoptera larvae (moth or butterfly caterpillars) and Formicidae (ants) also occurring frequently. Whitaker et al. (1994) found that Gastropoda (slugs and snails), Coleoptera (beetles-adults and larvae), Endogone spp. (fungi), and Annelida (earthworms) were taken in greatest frequency. Ladine and Muñoz (2010) reported that the most common food items chosen were Gastropoda (slugs and snails) and Orthoptera 
(grasshoppers and crickets). Whitaker and Ruckdeschel (2006) found Amphipoda (crustaceans), Coleoptera (beetles-larvae), and Chilopoda (centipedes) to have the greatest frequency of occurrence. It seems clear that diet preference in the southern short-tailed shrew is subject to local variation.

The southern short-tailed shrew appears to be choosing food items differently than other members of the genus Blarina. Ritzi et al. (2005) compared food items most frequently taken by the 3 species of Blarina. They showed that the northern short-tailed shrew (B. brevicauda) consumed significantly more soft-bodied insects such as earthworms (Annelida), whereas Elliot's short-tailed shrew (B. hylophaga) consumed significantly more hard-bodied insects, such as adult beetles (Coleoptera), compared to the other 2 species of shrews. Comparatively, the southern short-tailed shrew consumed more fungi than B. brevicauda and B. hylophaga. As noted above, the data on specific diet items of the southern short-tailed shrew across multiple studies show that the shrews feed on a wide range of animal and plant material. This suggests that the southern short-tailed shrew is more of a diet generalist compared to $B$. brevicauda and B. hylophaga, whereby they consume material that is of varying hardness.

Our study reports the first information on ectoparasites of the southern short-tailed shrew in Louisiana. Two ectoparasite species (Ornithonyssus bacoti and Ixodes scapularis) are new host records for $B$. carolinensis, whereas 5 mite species (Blarinobia simplex, Echinonyssus blarinae, Eucheyletia bishoppi, Orycteroxenus soricis, and Pygmephorus tamiasi) are new state records. Three of the mite species collected, Androlaelaps fahrenholzi (Pratt and Good 1954), O. bacoti (Williams 1946, Eckerlin et al. 1995), and Haemogamasus harperi (Whitaker et al. 2007), have been previously reported as occurring on other mammals in Louisiana. The highest diversity of ectoparasites was found from shrews captured in the grassland and open pine habitats. Also, ectoparasites were most prevalent in the spring season, with 6 species documented in that season.

Larvae of I. scapularis (blacklegged tick) were recovered from 2 shrews captured from open pine islands in the summer trap season. This is the first report of I. scapularis on the southern short-tailed shrew. Larvae of I. scapu- laris have been recovered from a large number of host species, including reptiles, birds, and mammals (Keirans et al. 1996), and they have also been recovered from deer in Louisiana (Kellogg et al. 1971, Jacobs et al. 2003). Ixodes scapularis is the primary vector for Borrelia burgdorferi, the spirochete causative agent of Lyme disease (Creager et al. 1990, Service 2004, Forbes et al. 2007). It also can vector the causative agents for Babesiosis (Babesia microti), Human Granulocytic Anaplasmosis (Anaplasma phagocytophilum), and tularemia (Francisella tularensis) (Stedman 2000, Service 2004, John and Petri 2006). Ornithonyssus bacoti (family Macronyssidae) was collected from one shrew captured in the open pine island habitat in the spring trap season. This parasite is known from multiple small and medium-sized mammals but has never been recovered from southern shorttailed shrews, even when the parasite was found in the same habitat on other mammals (Hays and Guyton 1958, Whitaker and Wilson 1974, Whitaker 1982, Whitaker et al. 2007). It is possible that this specimen of $O$. bacoti represents an unintentional association.

We thank the following faculty and staff of McNeese State University, namely Frederick LeMieux, William Dees, Juliana Hinton, and Jan Prudholmme, for their assistance with various aspects of this project. We also thank the park rangers and staff of Sam Houston Jones State Park, Don Foreman of Lebleu Settlement for the use of his land, and Tom Klei and Brian Ledet of Louisiana State University for their assistance in identifying the tick larvae. Partial funding was provided by the Department of Agriculture, McNeese State University. Finally, we thank one anonymous reviewer for comments on an earlier version of the manuscript.

\section{Literature Cited}

Baumgardner, G.D., N.O. Dronen, and D.J. Schmidly. 1992. Distributional status of short-tailed shrews (genus Blarina) in Texas. Southwestern Naturalist 37:326-328

Calhoun, J.B. 1941. Distribution and food habits of mammals in the vicinity of the Reelfoot Lake Biological Station. Journal of the Tennessee Academy of Science 16:177-185.

Creager, J.G., J.G. Black, and V.E. Davison. 1990. Microbiology principles and applications. Prentice Hall, Inc., Upper Saddle River, NJ. 839 pp. 
Eckerlin, R.P., H.F. Painter, L.A. Durden, and M.D. LiTTLE. 1995. Ectoparasites of wharf rats in New Orleans. Virginia Journal of Science 46:92.

Forbes, B.A., D.F. SAHM, AND A.S. WeIsSFELD. 2007. Bailey \& Scott's diagnostic microbiology. 12th edition. Mosby-Elsevier, St. Louis, MO. 1030 pp.

Gannon, W.L., R.S. Sikes, and Animal Care and Use Committee of the American Society of MamMALOGISTS. 2007. Guidelines of the American Society of Mammalogists for the use of wild mammals in research. Journal of Mammalogy 88:809-823.

Genoways, H.H., AND J.R. ChOATE. 1972. A multivariate analysis of systematic relationships among populations of the short-tailed shrew (genus Blarina). Systematic Zoology 21:106-116.

1998. Natural history of the southern short-tailed shrew, Blarina carolinensis. Occasional Papers of the Museum of Southwestern Biology 8:1-43.

George, S.B., H.H. Genoways, J.R. Choate, and R.J. BAKER. 1982. Karyotypic relationships within the short-tailed shrews, genus Blarina. Journal of Mammalogy 63:639-645.

Handley, C.O., JR. 1971. Appalachian mammalian geography-Recent Epoch. Pages 263-303 in P.C. Holt, R.A. Paterson, and J.P. Hubbard, editors, The distributional history of the biota of the southern Appalachians. Part III: vertebrates. Research Division Monograph, Virginia Polytechnic Institute and State University, Blacksburg, Virginia 4:1-306.

Hatchell, G.E. 1964. Small-mammal species and populations in the loblolly-shortleaf pine forest type of Louisiana. Southern Forest Experiment Station, USDA Forest Service, Department of Agriculture, New Orleans, Louisiana, Research Paper, SO-10:1-12.

Hays, K.L., AND F.E. GuYTON. 1958. Parasitic mites (Acarina: Mesostigmata) from Alabama mammals. Journal of Economic Entomology 51:259-260.

Jacobs, M.B., J.E. Purcell, And M.T. Philipp. 2003. Ixodes scapularis ticks (Acari: Ixodidae) from Louisiana are competent to transmit Borrelia burgdorferi, the agent of Lyme borreliosis. Journal of Medical Entomology 40:964-967.

John, D.T., And W.A. Petri, JR. 2006. Markell and Voge's medical parasitology. 9th edition. Saunders-Elsevier, Inc., St. Louis, MO. 463 pp.

Keirans, J.E., H.J. Hutcheson, L.A. Durden, and J.S.H. KLOMPEN. 1996. Ixodes (Ixodes scapularis) Say (Acari: Ixodidae): redescription of all active stages, distribution, hosts, geographical variation, and medical and veterinary importance. Journal of Medical Entomology 32:297-318.

KellogG, F.E., T.P. Kistner, R.K. Strickland, and R.R. GERRISH. 1971. Arthropod parasites collected from white-tailed deer. Journal of Medical Entomology 8:495-498.

Ladine, T.A., And A. Muñoz. 2010. Food habits of the southern short-tailed shrew (Blarina carolinensis) in east Texas. Texas Journal of Science 62:153-156.

Lowery, G.H., JR. 1974. The mammals of Louisiana and its adjacent waters. Louisiana State University Press, Baton Rouge, LA. xxiii + 565 pp.

Martin, R.P., R.B. Hamilton, P.M. McKenzie, R.H. Chabreck, And D.A. Dell. 1991. Habitat use by small mammals in coastal marshes of southwestern Louisiana. Estuaries 14:107-110.

Nims, T.N., L.A. Durden, C.R. Chandler, and O.J. PUNG. 2008. Parasitic and phoretic arthropods of the oldfield mouse (Peromyscus polionotus) from burned habitats with additional ectoparasite records from the eastern harvest mouse (Reithrodontomys humulis) and southern short-tailed shrew (Blarina carolinensis). Comparative Parasitology 75:102-106.

PASCAL, D.D., JR. 1984. A taxonomic study of midwestern short-tailed shrews (genus Blarina) with emphasis upon their ectoparasites. Doctoral dissertation, Indiana State University, Terre Haute, IN. xii + 185 pp.

PratT, H.D., AND N.E. GOOD. 1954. Distribution of some common domestic rat ectoparasites in the United States. Journal of Parasitology 40:113-129.

Ritzi, C.M., B.C. BARTEls, and D.W. SPARKS. 2005. Ectoparasites and food habits of Elliot's short-tailed shrew, Blarina hylophaga. Southwestern Naturalist 50:88-93.

SchmidLy, D.J. 1983. Texas mammals east of the Balcones Fault Zone. Texas A\&M University Press, College Station, TX. 400 pp.

1994. The mammals of Texas. Revised edition of: ibidem William B. Davis. Rev. 1974. University of Texas Press, Austin, TX. xviii + 501 pp.

SErvice, M. 2004. Medical entomology for students. 3rd edition. Cambridge University Press, New York, NY. $285 \mathrm{pp}$.

Stedman, T.L. 2000. Stedman's medical dictionary. 27th edition. Lippincott Williams \& Wilkins, Baltimore, MD. 2098 pp. + Vet 1-128 + MC 1-32.

Whitaker, J.O., JR. 1982. Ectoparasites of mammals of Indiana. Indiana Academy of Science, Indianapolis, IN. Monograph No. 4. xvi +240 pp.

Whitaker, J.O., JR., G.D. Hartman, and R. Hein. 1994. Food and ectoparasites of the southern short-tailed shrew, Blarina carolinensis (Mammalia: Soricidae), from South Carolina. Brimleyana 21:97-105.

Whitaker, J.O., JR., And C. Ruckdeschel. 2006. Food of the southern short-tailed shrew (Blarina carolinensis) on Cumberland Island, Georgia. Southeastern Naturalist 5:361-366.

Whitaker, J.O., JR., B.L. Walters, L.K. Castor, C.M. Ritzi, AND N. Wilson. 2007. Host and distribution list of mites (Acari), parasitic and phoretic, in the hair or on the skin of North American wild mammals north of Mexico: records since 1974. Faculty Publications from the Harold W. Manter Laboratory of Parasitology. Paper 1. University of Nebraska, Lincoln, NE.

Whitaker, J.O., JR., AND N. Wilson. 1974. Host and distribution lists of mites (Acari), parasitic and phoretic, in the hair of wild mammals of North America, north of Mexico. American Midland Naturalist 91:1-67.

Williams, R.W. 1946. The laboratory rearing of the tropical rat mite, Liponyssus bacoti (Hirst). Journal of Parasitology 32:252-256.

Received 7 October 2011 Acceptance 6 July 2012 